- FINANSE I PRAWO FINANSOWE.

- Journal of Finance and Financial Law $\bullet$

Grudzień/December 2020 • vol. 4(28): 79-99

http://dx.doi.org/10.18778/2391-6478.4.28.05

\title{
DEPOSIT GUARANTEE SYSTEMS IN RUSSIA AND THE USA
}

\author{
MA Tomasz Florczak \\ Faculty of Economics and Sociology, University of Lodz \\ ORCID: https://orcid.org/0000-0002-9111-3400 \\ MA Marta Paduszyńska \\ Faculty of Economics and Sociology, University of Lodz \\ ORCID: http://orcid.org/0000-0002-6156-0154
}

\begin{abstract}
The purpose of the article/hypothesis: The purpose of the article was to indicate the results of operations of deposit guarantee systems in Russia and the USA. The research hypothesis was that the deposit guarantee system in Russia during the 2004-2018 research period was more heavily burdened with guarantee activities.
\end{abstract}

Methodology: The article is largely based on a review, analysis and synthesis selected publications and available statistical data, and also expanded on the conclusions of the authors and the results of research in the discussed area.

Results of the research: The results of the conducted research indicate a high burden on the institution guaranteeing deposits in Russia (DIS). This is primarily the result of actions aimed at stabilizing the Russian banking sector.

Keywords: deposit guarantees, deposit guarantee systems, Russia, USA.

JEL Class: G20, G21, N2. 


\section{INTRODUCTION}

The financial sector plays an important role in the economy because provides financial intermediation, i.e. deals with the transfer of founds from savers to investors. At the same time, the importance of banking institutions has increased. The main activity of these institutions is the sale of financial products such as loans and deposits. Banks are a particularly important link in the financial system. Funds deposited with these institutions may be the basis for the creation of credit money. The bank, acting as an intermediary between borrowers and savers, accepts deposits from entities with financial surpluses and converts them into loans to entities with a financial shortage. There is a risk that if all depositors decide to withdraw their funds entrusted to the banks, they will not be able to meet their obligations and will be forced to liquidate their assets and thus declare bankruptcy. Therefore, an oversupply of credit, coupled with securitization, may form the basis of events leading to a financial crisis. The combination of the aforementioned factors may threaten the bank's insolvency and its bankruptcy [Semenova and Shapkin 2019: 2150-2155]. Moreover, there may be a contagion effect in which the closure of one bank causes panic in other banks, causing massive withdrawals of deposits from these institutions as well (a run on the bank) [Aharony and Swary 1983: 308-311]. In such situation, depositors may not receive funds entrusted to a given credit institution. This threat was revealed in particular during the financial crisis that emerged in 2007. Protection against this type of events is provided by deposit guarantee systems, which provide depositors with withdrawals of funds entrusted to the bank. They are a key element in maintaining confidence in the banking sector and ensuring financial stability. These systems operate in various forms and have many powers. Since the establishment of the first of them - the American Federal Deposit Insurance Corporation (FDIC) - one can observe the spread of deposit protection around the world. This issue creates an ever wider field of considerations, both theoretical and empirical.

\section{THE GENESIS AND FUNCTIONING OF DEPOSIT GUARANTEE SYSTEMS}

Deposit guarantee systems were established to protect funds deposited by customers in banks. This method of protecting funds was created as a result of crises on the financial market. Deposit protection brings two kinds of benefits [ $\mathrm{Li}$ et al. 2019: 2499-2502]:

1. It reduces the uncertainty among banks customers who have entrusted their funds to a given bank;

2. It reduces the systemic risk in the market. 
The idea of a deposit guarantee, although it has been in place for several decades, is quite new issue ${ }^{1}$. The first deposit guarantee system was established in the United States in 1933. The institution established under this system functions until today (2020). Further cases of the emergence of guarantee systems took place in Europe in highly developed countries. The $80 \mathrm{~s}$ and $90 \mathrm{~s}$ of the last century were a time when there was a big increase, and there was a „flood" of institutionalized deposit guarantee systems [Zdanowicz 2007: 14]. Initially, the countries set up their own institutions for guaranteeing deposits. The change took place in the 1980s, when work began on a common position of the European Union Member States on the subject of deposit guarantee systems [Baka 2005: 219].

The result of the aforementioned works was the Recommendation of the European Commission No. 87/63 / EEC issued in 1986. The Recommendation contains the most important elements of guaranteeing deposits in each Member State of the European Union. The legal act states that [Baka 2005]:

- The concept of deposit insurance should be synonymous with the protection of small depositors. Small depositors are people who are unable to determine the current situation and the correctness of the policy of the bank in which they deposit their funds;

- All banks should be obliged to participate in the deposit guarantee scheme. This should also include branches of foreign banks that operate in a given country.

- Deposit guarantee schemes can operate in private or public form. Both solutions were allowed due to differences between the banking sectors of the European Union Member States.

In 1998, the basic elements of deposit guarantee schemes were defined by the International Monetary Fund (IMF) [Zaleska 2007: 250-265]. As a result of the work of the IMF, standards for the functioning of deposit guarantees and their place in the financial sector and the economy were created.

The process of creating new guarantee funds and the convergence of the measures used, especially in Europe, was strengthened by the implementation of the European Parliament Directive, i.e. Directive 94/19/EC of the European Parliament and of the Council of 30 May 1994 on deposit guarantee schemes. This Directive has been replaced by Directive 2014/49 (DGSD), which is the legal basis for the recent actions of all deposit guarantee schemes in the EU. As a result of the above-mentioned changes, among others, the minimum guarantee levels were increased, where the transitional level was set at EUR 100,000 and is valid until today. banks.

${ }^{1}$ Looking at the period of operation of general economic theories, or the history of central 


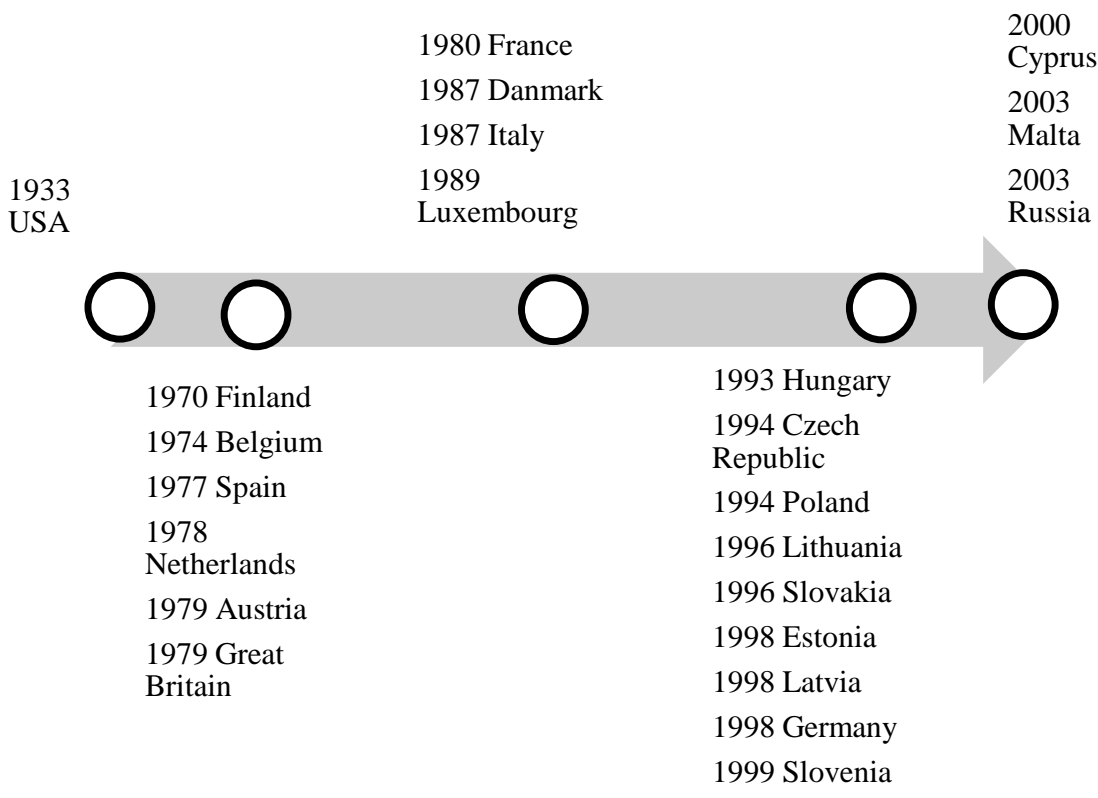

Figure 1. The history of the formation of deposit guarantee systems in Europe and the United States.

Source: own study based on: Baka 2005: 220; and websites of deposit guarantee systems of selected countries.

As can be seen from the presented illustration, the number of countries that have established deposit guarantee schemes has systematically increased. Moreover, according to the data of the International Association of Deposit Insurers $\left(\mathrm{IADI}^{2}\right)$ as of July 2019, the number of countries in which any form of explicit deposit insurance was established increased to 145 from 12 countries in 1974 [www1, accessed 15.03.2020].

After the financial crisis (2007-2009), which highlighted the financial weakness of many banks (including wrong risk management practices, systemically risky interconnections, and lack of sufficient supervision), a number of regulatory reforms were undertaken to address these shortcomings and create a more resilient financial system [Cerrone 2018: 224-239]. A key element of the changes was reducing the likelihood of bank failures and solving the problem of „too big to fail”. Supervision has been significantly strengthened by a set of

${ }^{2}$ The organization, established in 2002, brings together deposit insurers from all over the world in order to share knowledge and experience. From April 2020, the number of organizations belonging to this institution is 87 . 
uniform rules for the financial sector and their uniform application throughout the European Union.

Bank failures distort the allocation of capital and, in most cases, lead to falls in the real economy. One of the methods of prevention against the mass outflow of funds used by banking entities are deposit guarantees [Constantinescu 2015: 43-46]. People don't make withdrawals when they have confidence that their funds are safely insured [Rolnick 2010: 26-39]. If depositing with banks was generally considered risky, the ability of banks to perform their primary function of intermediation in the financial market would be limited. Hence, if the bank deposits can be fully guaranteed and the guarantee is reliable, then from the depositor's point of view, the funds entrusted by him are generally risk-free [Merton 1977: 3-11].

The deposit guarantee schemes mainly consist of guaranteeing deposits up to a certain predetermined value. The limits of the guaranteed funds are in many cases included in the legal act establishing the deposit guarantee institution. In practice, the most often there are limits on the value of guaranteed funds for one customer in a given bank. This means that the same client may also have guaranteed funds in another banking institution [Howarth and Quaglia 2018: 195201].

Policymakers have a variety of options concerning the protection of depositors. Countries can make explicit the protection of depositors in the case of a bank failure or they can leave the level of protection ambiguous, allowing the level and coverage of depositor protection implicit. Informal systems, i.e. systems of the implicit type, are characterized by the fact that when a systemic threat occurs, public institutions will take ad hoc measures. This may cause some uncertainty among institutions taking deposits and depositors as to the safety of the funds entrusted. Conversely, explicit and formal Explicit Deposit Guarantee Schemes are widely recognized as one of the most important elements of a credible safety net of the financial system. Under the open deposit guarantee system, on the closing date of an insolvent bank, the deposit guarantee institution pays out funds to eligible depositors up to the applicable limits. In this way, depositors are protected from losing their deposits [Chan et al. 2018: 73]. It is important that, from the point of view of the proper functioning of the system, it is based on extensive knowledge of the scope of protection of the contributions. Only then can it fulfill its role and prevent panic in the market. As stated by A. Demirgüç-Kunt and co-authors, every country without a clearly presented and regulated system [explicit) then has a systemtype of implicite, which results from the experience of the problems of the banking sector [Demirgüç-Kunt et al. 2007: 160-175]. Currently, most countries have a formalized deposit guarantee system, with a significant majority of developed countries. 
Four basic types of deposit guarantee institutions are listed below (in line with the literature on the subject). There are four basic types of deposit guarantee institutions. Individual types differ in the scope of competences of a given institution, its powers and the purpose of its operation. There are institutions operating on the basis of:

- paybox - the activities of the institution guaranteeing deposits are limited only to the payment of guaranteed deposits when the situation requires it [Pawlikowski 2004: 5-11];

- paybox-plus - the guaranteeing institution is entitled to disburse funds for guaranteed deposits and to restructure or orderly wind up banking institutions in difficulty [www2, accessed 22.04.2020];

- risk minimizer - the activities of the institution guaranteeing deposits include guarantee payments and taking actions to prevent bankruptcy of entities operating in a given banking sector - it is mainly related to granting financial aid [Pawlikowski 2004: 5-11];

- loss minimiser - the institution guaranteeing deposits is entitled to disbursements of guaranteed funds, to carry out assistance activities aimed at reducing the risk of bankruptcy of a given bank, recommendations and supervision of the implementation of a restructuring strategy for entities at risk and orderly liquidation of entities declared bankrupt [www3, accessed 22.04.2020].

The most frequently used institution is the one that operates on the paybox principle.

\section{DEPOSIT GUARANTEE SYSTEMS IN THE COUNTRIES OF THE FORMER USSR}

The history of the creation of deposit guarantee schemes shows that in market economy countries they were established earlier than in countries with a centrally planned economy. This regularity seems to be confirmed by the establishment of the first system in the USA in 1933. On the other hand, in Russia - the largest country created after the collapse of the socialist bloc, an institution guaranteeing deposits was established in 2003. Due to the specificity of countries with a centrally planned economy, an attempt was made to look closer on the functioning of the deposit guarantee systems in countries created after the collapse of the USSR (the countries which were separate socialist countries before the change of the political system, because most of them are members of the European Union and are covered by the Directive 2014/49 (DGSD).

In 1991, the social, economic and political structures of the Soviet Union began to disintegrate. Fifteen post-Soviet states gained independence and began to create their own institutional framework, including the domestic financial system. The frequent crises of the 1990s threatened the evolution of banking 
systems in which customers could place their trust, especially in an age where no deposit guarantee scheme existed yet [Savchenko and Kovács 2017: 29-42]. In 1996, Belarus and Lithuania were the first to set up a deposit guarantee system. Since then, also other countries, following this trail, began to introduce the abovementioned guarantee systems into their structures, as shown in the diagram below (Figure 2).

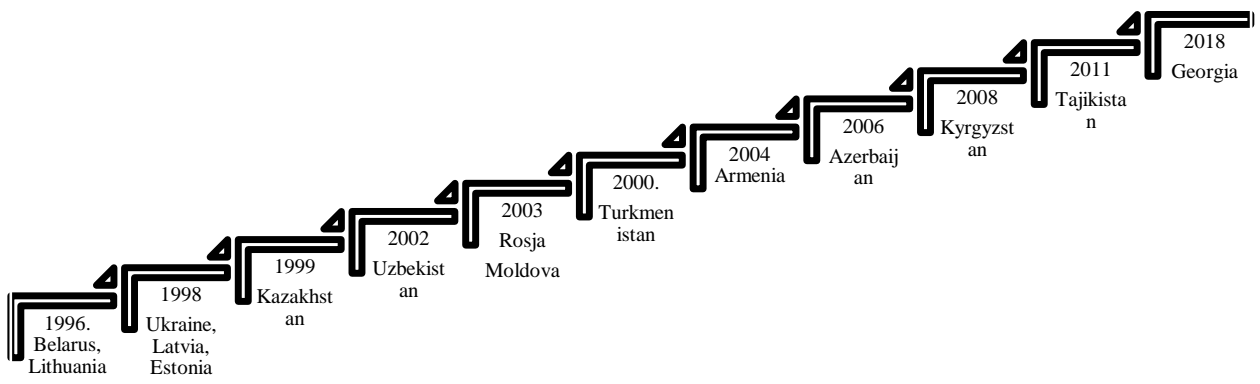

Figure 2. The history of the formation of deposit guarantee systems in post-Soviet countries.

Source: own study based on: Horsch et al. 2018: 27.

In line with the above timeline, deposit guarantee systems in the former Soviet Union countries were established in the period 1996-2018. The deposit guarantee systems in the former Soviet Union countries differ in form, the limit of guaranteed funds and the manner of their administration. The shape of the functioning of the contribution guarantee system in a given country depends on various factors. One of the dilemmas is the choice of establishing a separate fund or entrusting its powers to an already existing institution, usually the central bank. A comparative analysis of depository systems operating in the post-Soviet countries is presented in the table below (see Table 1). 


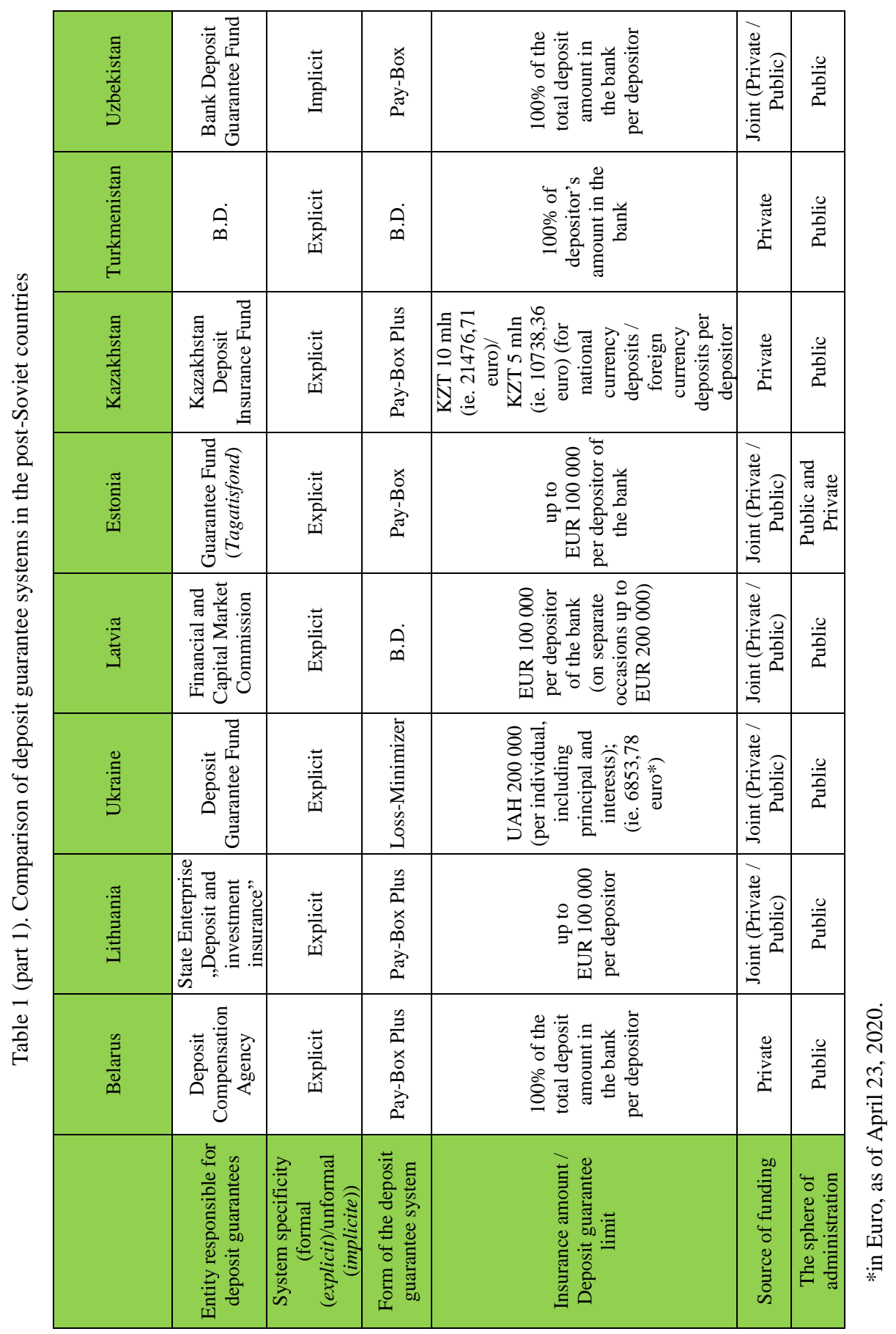




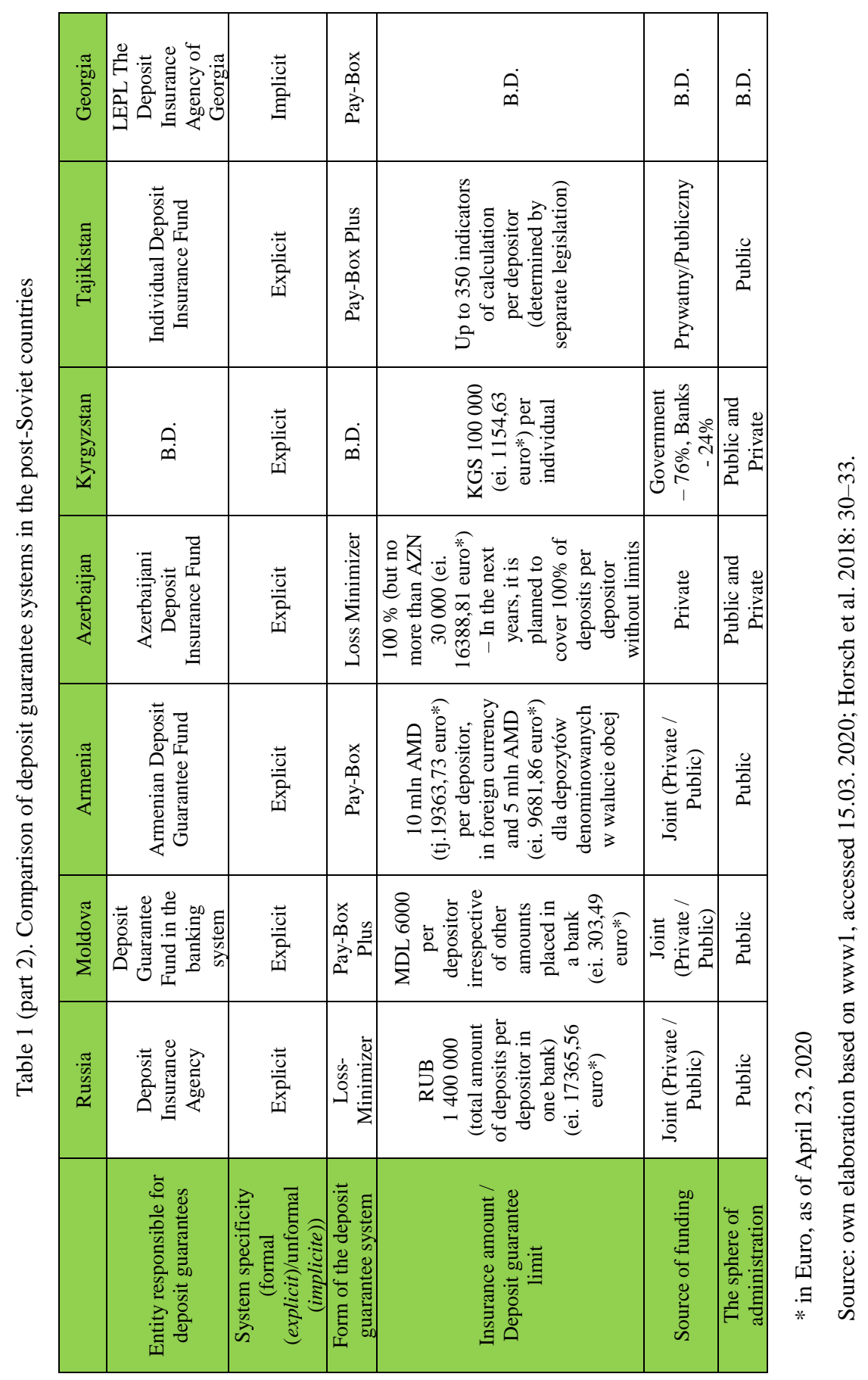


As it can be seen from the above data, in the vast majority of the former Soviet Union countries there is a formal deposit guarantee system, ie the explicit system. Only Uzbekistan and Georgia have the informal form of a deposit guarantee system. Each country applying the Explicit System shall define this margin coverage limit. This means that in the event of the closure of an insolvent bank, the deposit guarantee institution pays out funds to eligible depositors up to the applicable limits. As can be seen from the above data, their amount varies greatly. The limit can be expressed as an absolute number (amount in a specific currency) or as a percentage (percentage of deposited deposits, bank capital or other volumes [Demirgüç-Kunt et al. 2015: 160-172].

An important aspect of the operation of guarantee systems is the source of funds for the implementation of guarantee payments. These funds may come from members of the guarantee system or from other institutions of the country's financial safety net ${ }^{3}$. In particular, they may come from the state budget (then we are dealing de facto with government guarantees). Another way is financing only by banks that are members of the guarantee system. In such systems, there may also be participation in the costs of payments by other institutions, most often the central bank. Most post-Soviet depository protection systems are financed by the government and banks in certain proportions. Turkmenistan, Belarus, Kazakhstan and Azerbaijan operate deposit guarantee systems based solely on private funds, i.e. from banks and other financial institutions.

The administration of the guarantee system concerns many aspects, i.e. the specificity of legal regulations, the powers of the basic bodies managing the institution and its location in the national financial safety net. First of all, establishing the guarantee institution in the financial sector has a very important role. Generally, the administration of the deposit guarantee scheme can be of three types: it can be private, public or mixed. The criteria for selecting the appropriate method of administration is related to the way the institution was established ${ }^{4}$, it is also the result of historical conditions, as well as the current experience of managing financial security institutions in a given country [Obal 2004: 61]. Themanaging bodies may include representatives of various institutions. As for the administrative body, most of the post-Soviet countries have a public administration, as this form is considered to be the best way to maintain the efficiency of the deposit insurance system in an unstable economic environment

${ }^{3}$ The financial safety net is essential for maintaining the safety of financial institutions and markets. The activities of the institutions belonging to the network are to limit the possibility of financial problems arising in individual institutions subject to regulations, as well as systemic phenomena.

${ }^{4}$ If the guarantee system was created on a bottom-up initiative (that is, as a result of selfregulation of the banking community, it usually has a private administration, remaining fully under the control of the bank. In other cases, the central bank and/or finance ministries are more important). 
[Horsch et al. 2018: 35]. Adopting this form means that the guarantee system is managed by representatives of safety net institutions and the national authority.

The conducted analysis shapes a rather heterogeneous picture of depository systems in post-Soviet countries.

\section{DEPOSIT GUARANTEE SYSTEMS IN THE RESEARCHED COUNTRIES}

This study presents the effects of actions taken by institutions guaranteeing deposits in Russia and the United States. The deposit guarantee systems developed since the 1930s. This does not mean that all countries have had such structures for a long time.

In 1933, the world's first deposit guarantee institution was established in the United States. This shows how important the role of the banking sector has been in a country with a market economy for many years. On the other hand, Russia is a country that emerged after the collapse of the Soviet Union, where deposit guarantees were normalized in 2003. It is possible that this is a consequence of the crises in the banking sector and connected with this the country transition from a centrally planned economy to a market economy in the 1990s.

The deposit guarantee institutions in the surveyed countries are described below and the effects of their activity are presented.

\subsection{Russia}

Until 2004, there was no deposit protection system in banks in the Russian Federation. It was only the crisis of 1998 that realized the need to introduce a deposit guarantee system. The cause was massive withdrawals from banks a banking panic that led to the collapse of more than 200 banks in Russia.

On the basis of the Law „On insurance of household deposits with banks of the Russian Federation" (No. 177-FZ of 23.12.2003) ${ }^{5}$ the Deposit Insurance Agency (DIS) was established. The main purpose of DIS is to ensure the efficient operation of the insurance system for bank deposits of individual customers. This institution, together with the Bank of Russia, banks licensed to accept deposits from natural persons (banks entered in the register of banks covered by the deposit guarantee scheme) and depositors, forms a deposit guarantee scheme in Russia.

The Russian deposit guarantee system works in the form of a loss minimizer. The entity guaranteeing the deposits is entitled to:

${ }^{5}$ This law was passed by the State Duma on November 28, 2003, approved by the Council of the Russian Federation on December 10, 2003, and signed by the President of the Russian Federation on December 23, 2003. Published in Sobrania zakonodatielstwa Rossijskoj Fiedieraciji ot 29.12.2003, No. 52, item 5029. 
- return of insured funds to depositors upon the maturity of the guarantee,

- monitoring the accumulation of the deposit insurance fund,

- liquidation of failed banks,

- solving problems of systemically important banks,

- administration of guaranteeing the rights of the insured in the compulsory pension system.

Membership in DIS is compulsory for deposits of individual customers. Corporate deposits, bearer deposits and fiduciary deposits are excluded.

Since the implementation of the deposit guarantee system until 2018, the guaranteed amount increased fourteen times. In 2004, deposits were fully guaranteed up to the amount of 100 thousand RUB (\$ 1,545.13). In 2018, the guaranteed amount was 1.4 million rubles (deposits in foreign currencies are guaranteed up to the equivalent of 1.4 million RUB - when the guarantee is met, they are paid in rubles and converted at the exchange rate set by the CBR). The guaranteed amounts are paid to depositors from the fund of obligatory deposit insurance. The compulsory deposit insurance fund is the sum of cash and other assets that are used exclusively for payments for insuring personal deposits with Russian banks [Żukowska and Żukowski 2011: 60]. In 2005, 931 banks belonged to the system, ie approx. $77 \%$ of all credit organizations operating at that time. The banks participating in the system collected $99 \%$ of the total deposits of the population and managed $94.6 \%$ of the assets of the entire banking sector [Żukowska and Żukowski 2011: 70].

Four charts showing the results of the activities of the Deposit Insurance Agency are presented below:

- number of events requiring the fulfillment of the warranty,

- amount of guarantee payments,

- number of banks closed,

- the number of banks where restructuring activities were carried out.

The data presented in Figure 1 indicate the number of events in the Russian banking sector which required the fulfillment of a deposit guarantee. The chart shows two periods of increase in the number of events requiring the payout of guaranteed deposits. The first is 2008-2009. The increased number of warranty events was most likely related to the effects of the financial crisis [Domańska 2016: 1-3]. The second period is 2013-2018. The reduction in the number of banking institutions in the Russian banking sector and, at the same time, the increase in the number of events requiring the payment of deposit guarantees is related to the process of withdrawing licenses from banks that do not meet the requirements for operating in the sector, introduced since 2013 [Golubev et al. 2019: 3-5]. The data above confirm that the Russian deposit guarantee system is responding to developments in the banking sector. 


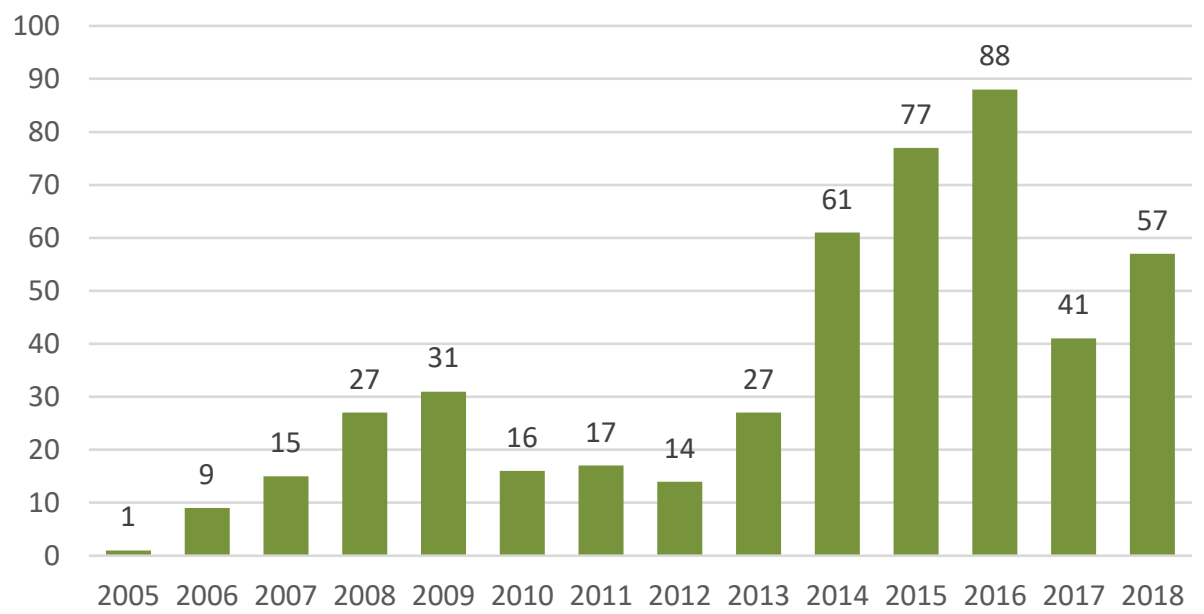

Chart 1. Number of events requiring the fulfillment of guarantees by DIS in 2005-2018

Source: own study based on: Annual report of the State Corporation „Deposit Insurance Agency" for 2018.

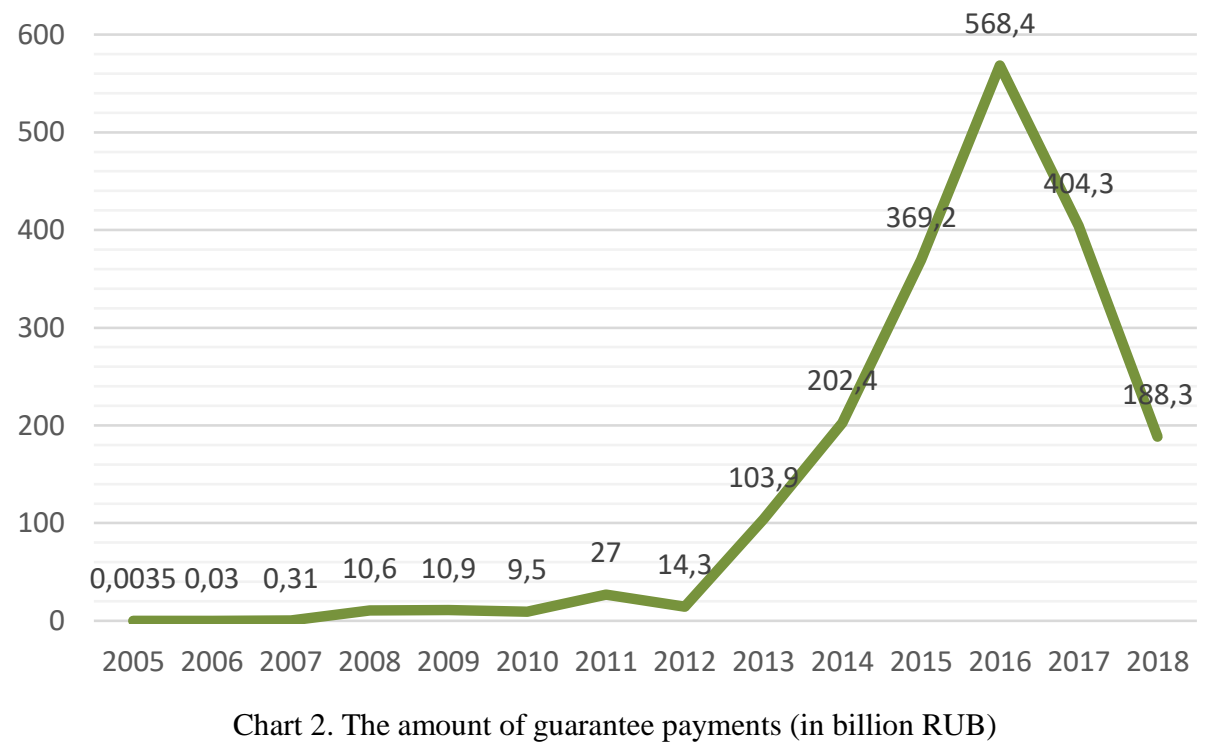

Source: own study based on: Annual report of the State Corporation „Deposit Insurance Agency" for 2018. 
Chart 2. presents data on the amount of disbursement of deposit guarantees. There is a noticeable difference between the amount of payments and the number of events that meet the conditions for the payment of guaranteed funds. You can see a steady increase in the payout value in the chart. The exception is 2012 , when there was a decrease in payments. Since 2013, the effects of the introduction of measures aimed at stabilizing the banking sector in Russia, and thus an increase in the concentration of banking sector assets, can be observed. Stabilizing activities are aimed at withdrawing licenses from non-compliant banks [Khromov 2017: 140]. The effect of withdrawing the license is an increase in the payment of deposit guarantee funds. In 2017-2018, a decrease in the value of payments can be observed. This may mean a slow stabilization in the Russian banking sector.

Chart 3 shows the increase in DIS activities in the scope of introducing receivership and liquidating banks. The data shows an increase in the activities of receivership in many entities. This means that banks were more often subject to organized liquidation. In few entities there was a situation that forced liquidation. As with the previous results of DIS activity, an increase in statistics for the period after 2013 can be observed.

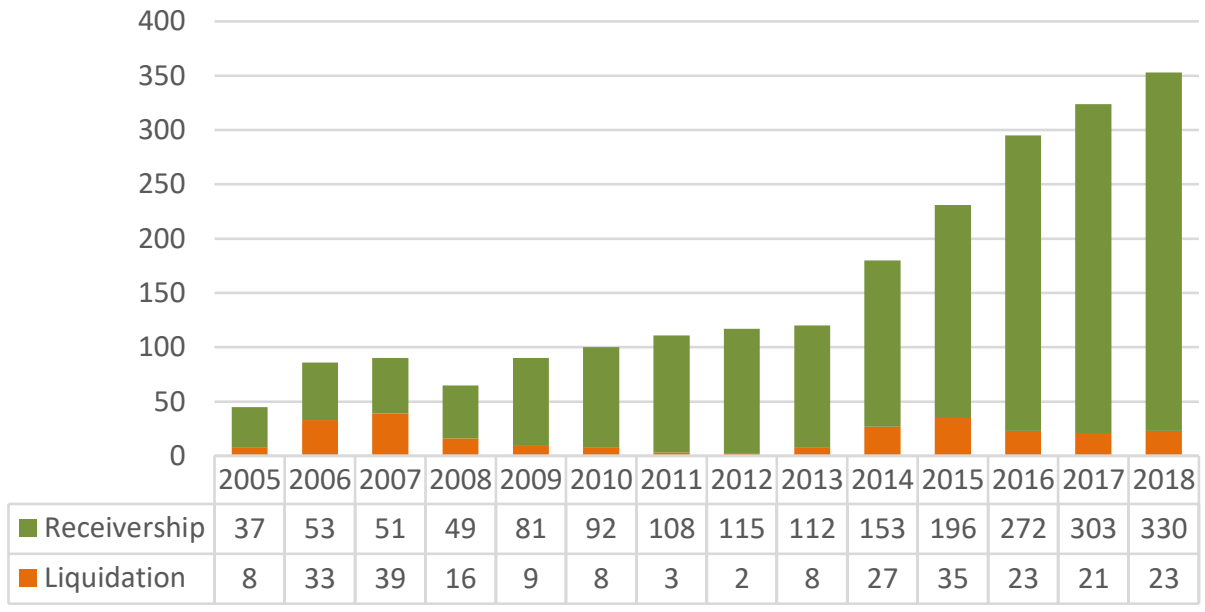

Chart 3. Number of liquidated banks

Source: own study based on: Annual report of the State Corporation „Deposit Insurance Agency" for 2018. 


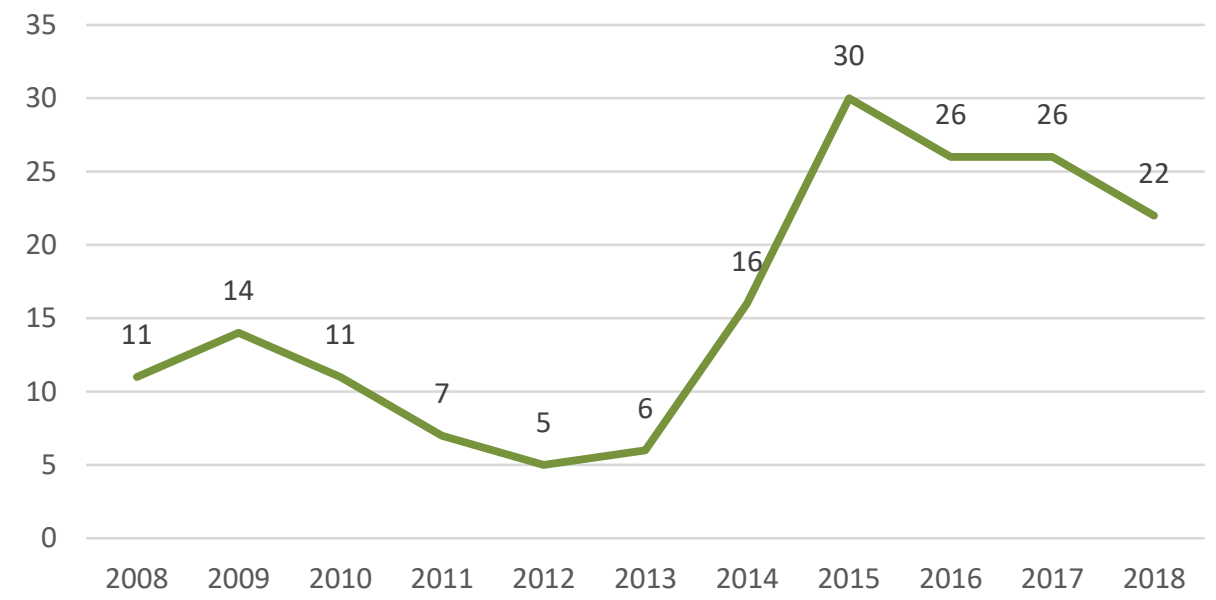

Chart 4. Number of banks where restructuring activities conducted by DIS were carried out

Source: own study based on: Annual report of the State Corporation „Deposit Insurance Agency" for 2018.

The last indicator covers the number of projects aimed at preventing bank failures at the end of the year. The chart shows data for the period 2008-2018 as DIS was granted restructuring powers in 2007. The data shows two periods of increased number of restructuring projects:

- 2008-2010,

- 2013-2018.

The activities for the period 2008-2010 were related to the global financial crisis. On the other hand, the increased number of corrective actions in the period 2013-2018 is due to the implementation of the enforcement of the rules governing the operation of banks in the Russian banking sector.

The data presented above indicate numerous activities of DIS in the area of disbursement of guaranteed deposits, liquidation and restructuring of banks. The intensified activities in the period 2013-2018 are primarily related to the introduction by the Central Bank of Russia in cooperation with the Russian Government of measures aimed at ensuring the stability of the Russian financial market. Since 2013, these actions resulted in the withdrawal of licenses from 332 banks that violated the laws regulating the Russian financial sector [Kruglova and Ushakova 2017: 5]. 


\subsection{United States}

The institution that guarantees deposits in the US is the Federal Deposit Insurance Corporation (FDIC). This entity was established in 1933 by the US Congress. This institution has the longest history among all functioning deposit guarantee institutions in the world. It covers banks that belong to the Federal Reserve system, as well as those state banks that have voluntarily agreed to participate in the system [Małecka and Włodarczyk 2012: 523-530].

The FDIC operates as a risk minimizer in order to maintain the stability of the banking sector, it has the power to:

- research and supervision of financial institutions in the field of consumer protection,

- restructuring of complex financial institutions,

- receivership.

Deposits covered by a guarantee

The deposit guarantees cover all types of deposits up to the equivalent of USD 250,000 per depositor.

The graphs below show the performance of the FDIC in the period 2004-2018. The study included three quantities:

- number of bank failures,

- value of deposits in banks that have failed,

- the number of active receivership.

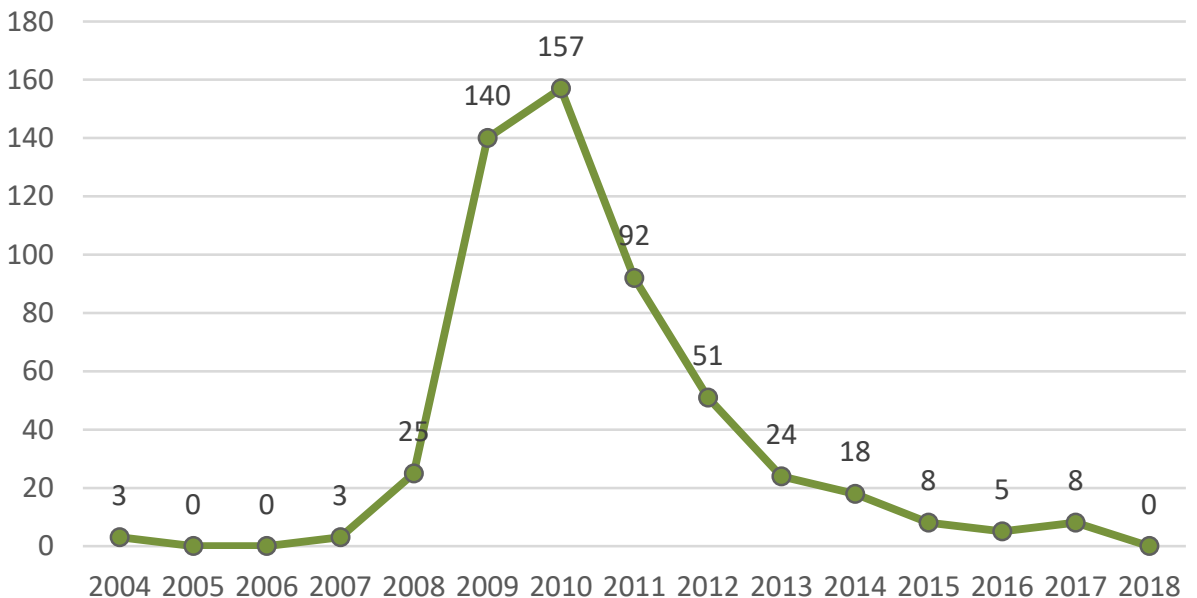

Chart 5. Number of bank failures in the US

Source: own study based on annual reports on the activities of the FDIC. 
Chart 5 shows the number of bank failures in the United States in the period 2004-2018. Data from the FDIC's annual reports show a significant increase in bankruptcies of banking institutions since 2008. The highest increase was recorded in 2009. However, the largest number of institutions went bankrupt in 2010. In the following years the number of institutions that became insolvent decreased to reach the level of 0 in 2018. It is probable that the large number of bank failures in 2008-2014 was affected by the financial crisis that began in 2007. The aforementioned crisis was of great importance for the changes in the US banking sector [Abdymomunov et al. 2019: 115-116].

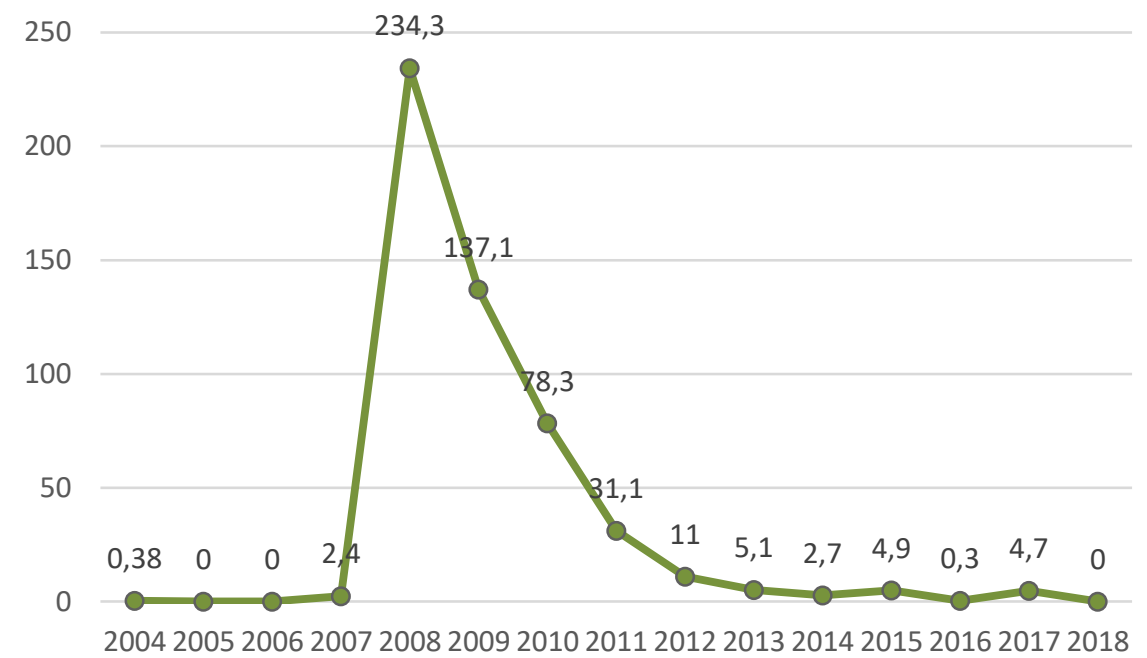

Chart 6. Value of deposits with banking institutions that went bankrupt with the US (in USD billion)

Source: own study based on annual reports on the activities of the FDIC.

The second important effect of the FDIC's operation is the value of deposits with banking institutions, the payment of which required at least partial coverage with funds from the deposit guarantee system. The value of this deposits increased very quickly in 2008 . These results were probably the result of the financial crisis in 2007. The highest value of deposits in bankrupt entities for 2008 shows that in this period the problems most probably faced the biggest banks with which significant funds were deposited. After 2008, a downward trend in the value of deposits in bankrupted banks is noticeable.

Another effect of the FDIC's operation is the number of active receivership boards in bankruptcy institutions. The receivership is aimed at, among others, the orderly liquidation of the entity, resale of its assets and payment of creditors. The 
figures given represent active receivership. This means that these institutions are currently conducting receivership actions initiated in this year and in previous years. The number of active receivership is shown in Chart 7.

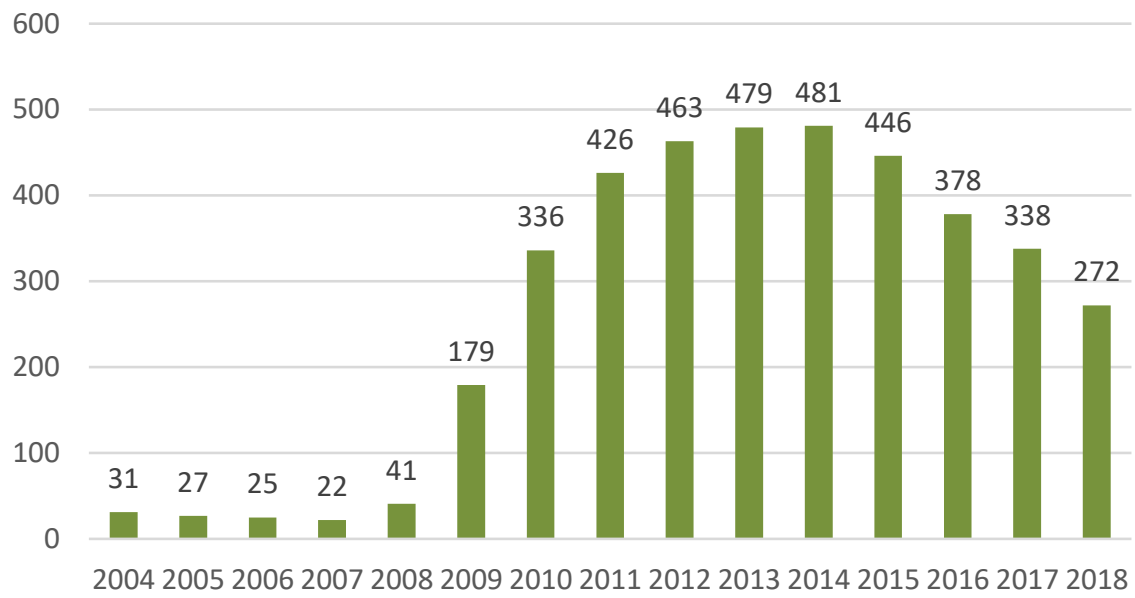

Chart 7. Number of active receivership boards over institutions subject to bankruptcy

Source: own study based on annual reports on the activities of the FDIC.

The chart above shows changes in the number of active receivership. The data presented in Chart 7 show the role of the financial crisis of 2007-2009 for the increase in the introduced measures related to the liquidation of banking institutions [Abdymomunov et al. 2019: 115]. The highest number of active receivership was observed in 2014. Since then, the FDIC has dissolved more receivership than it introduces. According to the data from the FDIC report (FDIC, 2018 ) in 2018 the number of new receivership boards was 0 , while the number of dissolved boards was 66. This means that the banking sector in the United States is probably stabilizing. The number of entities at risk of bankruptcy is decreasing.

The results of the FDIC's activities indicate that the United States' deposit guarantee institution is fulfilling its tasks well. The 2007-2009 financial crisis was a kind of test for the operational efficiency of the FDIC. During this period, there was a noticeable increase in the demand for the activities of the deposit guarantee institution. The current data point to the smooth operation of the FDIC and the slow stabilization of the situation in the US banking sector. 


\section{CONCLUSIONS}

The protection of deposits placed in banking systems is certainly an essential element to ensure an appropriate degree of confidence in the financial system. The lack of such protection significantly increases the risk of disruptions to the sector's liquidity, because as a result of the ,banking panic” it may lead to a crisis in the entire banking sector and result in many negative consequences for the entire economy. When considering the formula for the functioning of the deposit guarantee system in individual countries, a number of criteria should be taken into account. First of all, the fact for what purpose the institution was established. Taking a holistic view, not only internal factors (economic conditions, condition of the financial sector, legal regulations in a given country) will be important, but also a number of external factors, such as, for example, international standards (e.g. guidelines of the International Monetary Fund), regulations at the global level, solutions adopted in other countries and their experiences with the functioning of deposit guarantee schemes.

The authors achieved the goal by reviewing the literature on deposit guarantee systems in the studied countries and presenting the most important effects of their activities. Institutions guaranteeing deposits in these countries differ in the form of operation and the scope of competence. They also differ in the length of the functioning period - experience. FDIC (USA) was established in 1933, while DIS (Russia) was established in 2003. The conducted research seems to confirm the accepted research hypothesis that the institution guaranteeing deposits in Russia is more burdened with systemic activities. During its operation, DIS has undergone two periods of intense work. The first was related to the outbreak of the global financial crisis. The second is the result of the actions of DIS and the Central Bank of Russia (Central Bank of Russia) aimed at liquidating entities that do not meet the requirements for functioning in the Russian banking sector. Until 2018, a high number of bank liquidations, the size of guarantee payments and restructuring activities in entities at risk are noticeable. In the case of deposit guarantee institutions in the United States, the worst period with the beginning of the 2007-2009 financial crisis should be mentioned. The effects of the crisis are still visible in the number of receiverships in the US banking sector.

\section{BIBLIOGRAPHY}

Abdymomunov A, Curti F., Mihov A, 2019, U.S. Banking Sector Operational Losses and the Macroeconomic Enviroment, „Journal of Money, Credit and Banking”, vol. 52, no. 1.

Aharony J., Swary I., 1983, Contagion Effects of Bank Failures: Evidence from Capital Markets, „Journal of Business”, vol. 56, no. 3.

Baka W. (red.), 2005, Systemy gwarantowania depozytów w Polsce i na świecie: dziesięć lat Bankowego Funduszu Gwarancyjnego, PWE, Warszawa. 
Cerron R., 2018, Deposit guarantee reform in Europe: does European deposit insurance scheme increase banking stability?, „Journal of Economic Policy Reform”, vol. 21, no. 3.

Chan A., Godwin A., Ramsey I., 2018, Depositor preference and deposit insurance schemes challenges for regulatory convergence and regulatory coordination in Asia, „Law and Financial Markets Review", vol. 12, no. 2.

Constantinescu L.A., 2015, Challenges For Deposit Insurance And Financial Stability In European Cooperative Banks, „Knowledge Horizons - Economics”, vol. 7, no. 3.

Demirgüç-Kunt A., Kane E.J., Laeven L., 2007, Determinants of Deposit-Insurance Adoption and Design, ,Journal of Financial Intermediation”, vol. 17(3).

Demirgüç-Kunt A., Kane E.J., Laeven L., 2015, Deposit insurance around the world: A comprehensive analysis and database, „Journal of Financial Stability”, vol. 20.

Domańska M., 2016, Rosyjski sektor bankowy: rok w kryzysie, Komentarze OSW Ośrodek Studiów Wschodnich im. Marka Karpia, nr 204 [accessed 24.03.2016].

Official Journal of the European Communities, L 135/5, Directive 94/19 / EC of the European Parliament and of the Council of 30 May 1994 on deposit-guarantee schemes.

FDIC, 2018, Federal Deposit Insurance Corporation, Annual Report.

Golubev A., Rodionov A., Ryabov O., 2019, Analysis of the transformation of the Russian banking system, IOP Conf. Series: Materials Science and Engineering 497, doi:10.1088/1757899X/497/1/012041.

Horsch A., Sysoyeva L., Bogma S., 2018, Deposit insurance systems of post-Soviet countries: A comparative analysis, „Journal of International Studies”, vol. 11(4).

Howarth D., Quaglia L., 2018, The difficult construction of a European Deposit Insurance Scheme: A step too far in Banking Union?, ,Journal of Economic Policy Reform”, vol. 21.

Khromov M., 2017, Russia's banking sector, [w:] Sinelnikov-Murylev (red.), Russian Economy in 2016, Trends and Outlooks (Issue 38), Moskwa.

Kruglova A., Ushakova Y., 2017, Effect of Banking Sector Resolution on Competition and Stability, „Bank of Russia Working Papers”, no. 22.

Li B.Z.L., Zhou Y., Yang W., 2019, How Does Information Disclosure Affect Bank Systemic Risk in the Presence of a Deposit Insurance System?, „Emerging Markets Finance and Trade”, vol. 55:11, p. 2497-2522.

Małecka E., Włodarczyk B., 2012, Systemy gwarantowania depozytów - konwergencja rozwiazań stosowanych w krajach Unii Europejskiej, „Zarządzanie i Finanse”, r. 10, no. 4, p. 1, 521-535.

Merton R.C., 1977, An Analytic Derivation of the Cost of Deposit Insurance and Loan Guarantees, „Journal of Banking and Finance”, vol. 1, p. 3-11.

Obal T., 2004, Podstawowe cechy systemów gwarantowania depozytów i działalności pomocowej w państwach Unii Europejskiej - wnioski dla Polski, „Bezpieczny Bank”, nr 1 (22).

Pawlikowski A., 2004, Zróżnicowanie systemów gwarantowania depozytów. Analiza różnych wariantów rozwiązań, „Bank i Kredyt”, no. 10.

Rolnick A.J., 2010, Interview with Thomas Sargent, „Federal Reserve Bank of Minneapolis The Region", June.

Savchenko T.G., Kovács L., 2017, Trust in the banking sector: EU experience and evidence from Ukraine, „Financial Markets, Institutions and Risks”, vo. 1(1).

Semenova M., Shapkin A., 2019, Currency Shifts as a Market Discipline Device: The Case of the Russian Market for Personal Deposits, „Emerging Markets Finance and Trade”, vol. 55, p. 2149-2163.

Zaleska M., 2007, Wspótczesna bankowość. Tom I, Difin, Warszawa.

Zdanowicz B., 2007, Podstawowe dylematy i kryteria wyboru formuly systemu gwarantowania depozytów w świetle teorii i doświadczeń międzynarodowych, „Bezpieczny Bank”, t. 1, no. 34.

Żukowska H., Żukowski M., 2011, System gwarancji depozytów bankowych osób fizycznych w Rosji, „Bezpieczny Bank”, t. 3, no. 45. 
[www 1] https://www.iadi.org/en/deposit-insurance-systems/dis-worldwide/ [accessed 15.03.2020].

[www 2] https://www.iadi.org/en/core-principles-and-research/publications/glossary/paybox-plus/ [accessed 22.04.2020].

[www 3] https://www.iadi.org/en/core-principles-and-research/publications/glossary/lossminimiser/ [accessed 22.04.2020]. 